\title{
Effect of Bio-Fertilizer and Kitchen Waste Manure on Growth of Chilli cv. Pusa Jwala
}

\author{
Vinit Kumar Meena*, Sutanu Maji, Rakesh Kumar Meena and Batti Lal Meena \\ Department of Horticulture, Babasaheb Bhimrao Ambedkar University, \\ Vidya-Vihar, Rae Bareli Road, Lucknow-226025, India \\ *Corresponding author
}

\section{A B S T R A C T}

\begin{tabular}{|l|}
\hline Key w or d s \\
Bio-fertilizer, \\
growth,chilli, \\
pusa jwala
\end{tabular}

An experiment was carried out at the Horticulture Research Farm, Department of Applied Plant Science (Horticulture) Babasaheb Bhimrao Ambedkar University (A Central University), Lucknow to Effect of biofertilizer and kitchen waste manure on vegetative growth of chilli cv. Pusa Jwala. The results revealed that the that application of treatment $\mathrm{T}_{10}[\mathrm{RDF}$ $50 \%+$ kitchen waste manure (25 and 50 days after transplanting)] was found to be the best treatment in respect of betterment of vegetative growth except treatment $\mathrm{T}_{7}(\mathrm{RDF} 50 \%+$ kitchen waste manure) showed the early flowering to harvesting (23.67 days).

\section{Introduction}

Pepper (Capsicum sp.) is an economically important vegetable crop belonging to the family solanaceae having chromosome number $\mathrm{n}=12$ (Thambhuraj and Singh, 2015). It originated from South and Central America where it is still under cultivation (Pickersgill, 1997). Pepper was introduced into Europe by Columbus and other early new explorers in the sixteenth century and cultivation spread throughout the world (Greenleaf,1986). Chilli (Capsicum annum var. frutescence) is one of the most important vegetable crops grown throughout India. It is grown for export as well as for domestic market. Chilli is a heavy feeder crop so, it needs higher amount of nutrient according to recommended that $150 \mathrm{~kg} / \mathrm{ha}$ Nitrogen, 75 $\mathrm{kg} / \mathrm{ha}$ Phosphorus, $75 \mathrm{~kg} / \mathrm{ha}$ Potassium.

It is used for good growth and yield for production of chilli proper supply sufficient amount of nutrient by inorganic source. But now a days, inorganic or chemical fertilizer can be reduce the soil fertility, plant growth, flowering and yield as well as it affect the quality of chilli. thus I have used to biofertilizer like Azospirillum in chilli crop because it help to convert the atmospheric 
nitrogen in available nitrogen form and increases the growth, no of leaves, flowering, fruiting, yield and biochemical property in fruit as well as in kitchen waste manure good amount of nutrient because it is made by plant origin like leaves, flower, peel, seed etc. kitchen waste manure is not only good amount in nutrient as well as clean area and provide fresh air because disposed the kitchen garbage and it increase the microbial activity, soil porosity, water retention and reducing the $\mathrm{pH}$ level. It is used for increase the growth yield and quality of chilli.

\section{Materials and Methods}

The experiment was carried out at the Horticulture Research Farm, Department of Applied Plant Science (Horticulture) Babasaheb Bhimrao Ambedkar University (A Central University), Vidya Vihar, Rae Barely Road, Lucknow during October 2016 - May 2017.Geographically, experimental field is situated at an elevation of 123 meter above Mean Sea Level (MSL) in the Sub-tropical Climate of Central Uttar Pradesh at $26^{0} 55^{\prime}$ North latitude and $80^{\circ} 59^{\prime}$ East longitude. The experiment was laid out in Randomized Block Design (RBD) with three replications. Total plot size $2.16 \mathrm{~m}^{2}$, total no. plot 36 along with $30 \times 30 \mathrm{~cm}$. The seeds of chilli (Capsicum annum var. frutescence) cv. Pusa Jwala were obtained from the Indian Agricultural Research Institute, Pusa, New Delhi.

Before the seed sowing, the nursery field was ploughed, harrowed and the soil was brought to a fine tilth. Raised nursery beds were prepared at a height of $15 \mathrm{~cm}$ with $1 \mathrm{~m}$ width and $2 \mathrm{~m}$ length. Well-decomposed compost at $2 \mathrm{~kg}$ per meter cube and NPK complex fertilizer was applied 15 days before sowing. Seeds of chilli variety Pusa Jwala sown after treating the seeds with 0.2 percent captan. Seeds of chilli were sown in rows and after sowing the lines were covered with fine
FYM. Healthy seedling of 35 days old with 46 true leaves were transplanted in main field.

Well-rotted Farmyard manure applied as per the treatments one month prior to transplanting. The other inorganic sources of nitrogen, phosphorous and potassium were applied in the form of urea, di ammonium phosphate and muriate of potash respectively at recommended dose. Full dose of phosphorous and potassium and half dose of nitrogen was applied to the treatments receiving Farmyard manure and Azospirillum inoculation, while the remaining treatments received full dose of recommended dose of nitrogen (RDN) $150 \mathrm{~kg} \mathrm{~N} / \mathrm{ha}$ in two splits doses and $50 \%$ RDN (in two splits) as per treatment specifications at the time of transplanting. The roots of chilli seedlings were dipped in solution containing Azospirillum inoculation and left for 15 minutes before transplanting as per the treatment specifications. The solution was made by adding juggary in sterile distilled water.

\section{Results and Discussion}

It revealed (Table 1) that application of $50 \%$ Recommended dose of fertilizers (RDF) and kitchen waste manure applied at 25 and 50 days after transplanting ( $\mathrm{T}_{10}$ treatment) increased the plant height at maximum ratei.e. $66.83 \mathrm{~cm}$ at 120 days after transplanting, respectively followed by $\mathrm{T}_{4}(50 \% \mathrm{RDF}+$ Azospirillum application at the time of transplanting) and $\mathrm{T}_{9}(50 \% \mathrm{RDF}+$ Kitchen waste manure at 25 days of transplanting while, the minimum height was recorded under control plant $\left(\mathrm{T}_{0}\right)$. Similarly, Natarajan (1990) also observed that chilli cultivars Local and CA- 42 when inoculated with Azospirillum in combination with $75 \%$ of recommended nitrogen produced higher plant height $(56.13 \mathrm{~cm}$ and $57.86 \mathrm{~cm}$, respectively). It was also observed that $\mathrm{T}_{10}$ i.e. treatment 
with 50\% RDF and kitchen waste manure applied at showed the maximum number of branches per plant at 120 days after transplanting 27.81, respectively) followed by $\mathrm{T}_{4}(50 \% \mathrm{RDF}+$ Azospirillum at the time transplanting) as similar trend observed in case of plant height. Seedling treatment with Azospirillum and 50\% RDF application $\left(\mathrm{T}_{3}\right)$ also had a better result to increase the number of branches

The maximum number of leaves were counted under treatment $\mathrm{T}_{10}(50 \% \mathrm{RDF}$ and kitchen waste manure 186.50but, there was a negligible statisitical difference among most of the treatments (Table 1). In general, all the treatments increase the number of leaves as compared to the control plants and some of the treatment effect (except $\mathrm{T}_{7}$ ) were better than the $100 \%$ RDF treatment $\left(T_{1}\right)$.

To find out $\mathrm{T}_{10}$ treatment $(50 \% \mathrm{RDF}$ and kitchen waste manure showed the maximum average spreading of plant $(39.20 \mathrm{~cm}$, respectively) at 120 days after transplanting followed by $\mathrm{T}_{4}(50 \% \mathrm{RDF}+$ Azospirillum at the time transplanting) while the minimum average spreading of per plant was recorded under control plant $\left(\mathrm{T}_{0}\right)$. Siddesh (2006) also observed that application of Azospirillum to chilli plants with $70 \mathrm{~kg} \mathrm{~N}$ per ha produced the higher branches (11.2/plant) respectively. The observation on flowering revealed that early flowering was initiated by the application of $50 \%$ RDF and kitchen waste manure showed (79.30 days from transplanting) followed by 82.30 days in $\mathrm{T}_{4}$ i.e. $50 \% \mathrm{RDF}+$ Azospirillum at the time transplanting and 84.3 days at $\mathrm{T}_{9}$ (50\% RDF + Azospirillum; soil application at transplanting) while the late flowering was recorded under control plant $\left(\mathrm{T}_{0}\right)$. Deshpande et al., (2010) also examined and found that the treatment N $125 \mathrm{~kg}$ / ha + FYM @ $10 \mathrm{t} / \mathrm{ha}$ + Azospirillum reported more plant height, number of braches per plant, days to first 50 $\%$ flowering, days to first harvest, number of fruits per plant, weight of individual fruit, fruit length, fruit diameter, yield of fresh red fruits, while least values for all above characters were recorded in control (N 150 kg/ha + FYM @ 10 t/ha).

The early flowering (Table-2) also caused early harvesting of green chilli fruits. Plants under $\mathrm{T}_{10}$ showed the early harvesting from transplanting (107.67 days) followed by 109.00 days from transplanting date under $\mathrm{T}_{4}(\mathrm{RDF} 50 \%+$ Azospirillum at the time transplanting). Late flowering in control plants lead to late harvesting from transplanting. However, Jeevansab (2000)reported that Azospirillum + RDF (150:75:50) took more number of days (37.81 days) to 50 per cent flowering as compared to RDF (36.6) alone in capsicum. But, Sutagundi (2000) reported early flowering (43.66 days) in plants when treated with FYM (10 t/ha) as compared to 100:50:50 kg NPK per ha (43.75 days) in chilli.

Maximum fruit set $(96.07 \%)$ was recorded under treatment $\mathrm{T}_{10}$ followed by $\mathrm{T}_{4}$. The significant fruit se increase was observed in all the treated plants a compared to control plants. This increase also reflected in case of number of fruits per plants after 10 harvesting. Control plants showed minimum fruit numbers than the other treatments, Sajan et al., (2002) studied the effect of biofertilizers combined with different $\mathrm{N}, \mathrm{P}$ and $\mathrm{K}$ fertilizer rates on the growth and yield of chilli cv. Byadagi Dabba. They showed that plants inoculated with Azotobacter, Azospirillum, PSB and VAM in combination with $75 \% \mathrm{NPK}+100 \% \mathrm{~K}$ recorded $36 \%$ more fruits per plant (111.38) and 45\% more dry fruit yield $(2.27 \mathrm{t} / \mathrm{ha})$ compared to the control (81.68 and $1.56 \mathrm{t} / \mathrm{ha}$, respectively). 
Table.1 Five different Vegetative growth parameters in chilli

\begin{tabular}{|c|c|c|c|c|c|}
\hline \multirow[t]{2}{*}{ Treatment } & \multicolumn{5}{|c|}{ Vegetative growth parameters } \\
\hline & $\begin{array}{c}\text { Plant } \\
\text { height }(\mathrm{cm})\end{array}$ & $\begin{array}{c}\text { Number } \\
\text { of } \\
\text { branches }\end{array}$ & $\begin{array}{l}\text { Number } \\
\text { of leaves }\end{array}$ & $\begin{array}{c}\text { Average } \\
\text { Spreading } \\
\text { of plant } \\
\text { (cm) }\end{array}$ & $\begin{array}{l}\text { Days required } \\
\text { for first } \\
\text { flowering after } \\
\text { transplanting }\end{array}$ \\
\hline $\mathrm{T}_{0}-$ Control & 51.91 & 16.67 & 129.39 & 27.17 & 94.7 \\
\hline $\mathrm{T}_{1}-100 \% \mathrm{RDF}(\mathrm{NPK})$ & 56.02 & 23.42 & 167.00 & 34.77 & 90.0 \\
\hline $\begin{array}{l}\mathrm{T}_{2}-\mathrm{RDF} 50 \%+\text { Azospirillum } \\
\text { (soil application before } \\
\text { transplanting) }\end{array}$ & 62.75 & 24.83 & 171.67 & 35.43 & 86.3 \\
\hline $\begin{array}{l}\mathrm{T}_{3}-\mathrm{RDF} 50 \%+\text { Azospirillum } \\
\text { ( Seedling treatment ) }\end{array}$ & 64.33 & 26.16 & 176.92 & 35.90 & 86.0 \\
\hline $\begin{array}{l}\mathrm{T}_{4}-\mathrm{RDF} 50 \%+\text { Azospirillum } \\
\text { (soil application at transplanting } \\
\text { treatment) }\end{array}$ & 64.92 & 26.79 & 178.83 & 38.20 & 82.3 \\
\hline $\begin{array}{l}\mathrm{T}_{5}-\mathrm{RDF} 50 \%+\text { Azospirillum } \\
\text { (at } 25 \text { days after transplanting) }\end{array}$ & 58.75 & 23.63 & 153.67 & 34.93 & 87.3 \\
\hline $\begin{array}{l}\mathrm{T}_{6}-\mathrm{RDF} 50 \%+\text { Azospirillum } \\
\text { (at } 25 \text { and } 50 \text { days after } \\
\text { transplanting) }\end{array}$ & 61.25 & 24.70 & 158.25 & 34.00 & 88.3 \\
\hline $\begin{array}{l}\mathrm{T}_{7}-\mathrm{RDF} 50 \%+\text { kitchen waste } \\
\text { manure (soil application before } \\
\text { transplanting ) }\end{array}$ & 59.08 & 23.80 & 153.50 & 34.83 & 89.0 \\
\hline $\begin{array}{l}\mathrm{T}_{8}-\mathrm{RDF} 50 \%+\text { kitchen waste } \\
\text { manure (at the time of } \\
\text { transplanting ) }\end{array}$ & 63.00 & 25.90 & 174.50 & 34.40 & 85.7 \\
\hline $\begin{array}{l}\mathrm{T}_{9}-\mathrm{RDF} 50 \%+\text { kitchen waste } \\
\text { manure ( } 25 \text { days after } \\
\text { transplanting ) }\end{array}$ & 64.00 & 26.38 & 174.58 & 35.60 & 84.3 \\
\hline $\begin{array}{l}\mathrm{T}_{10}-\mathrm{RDF} 50 \%+\text { kitchen waste } \\
\text { manure }(25 \text { and } 50 \text { days after } \\
\text { transplanting })\end{array}$ & 66.83 & 27.81 & 186.50 & 39.20 & 79.3 \\
\hline $\begin{array}{l}\mathrm{T}_{11}-100 \% \text { kitchen waste manure } \\
\text { (at the time of transplanting) }\end{array}$ & 59.42 & 23.50 & 156.08 & 35.30 & 86.7 \\
\hline $\operatorname{SEm}( \pm)$ & 0.986 & 0.491 & 5.417 & 0.324 & 1.486 \\
\hline CD $(P=0.05)$ & 2.709 & 1.449 & 15.990 & 15.990 & 4.388 \\
\hline
\end{tabular}


Table.2 Five different Vegetative growth parameters in chilli

\begin{tabular}{|c|c|c|c|c|c|}
\hline \multirow[t]{2}{*}{ Treatment } & \multicolumn{5}{|c|}{ Vegetative growth parameters } \\
\hline & $\begin{array}{c}\text { Days to first } \\
\text { harvesting after } \\
\text { transplanting in } \\
\text { chilli }\end{array}$ & $\begin{array}{c}\text { Fruit set } \\
\%\end{array}$ & $\begin{array}{l}\text { Individual } \\
\text { average fruit } \\
\text { weight (g) }\end{array}$ & $\begin{array}{l}\text { Thickness } \\
\text { of } \\
\text { pericarp } \\
\text { (mm) }\end{array}$ & $\begin{array}{c}\text { Days from } \\
\text { flowering } \\
\text { to } \\
\text { harvesting }\end{array}$ \\
\hline $\mathrm{T}_{0}-$ Control & 120.67 & 80.67 & 2.11 & 0.75 & 26.00 \\
\hline $\mathrm{T}_{1}-100 \%$ RDF ( NPK ) & 118.00 & 84.12 & 2.58 & 0.82 & 28.00 \\
\hline $\begin{array}{l}\mathrm{T}_{2}-\mathrm{RDF} 50 \%+\text { Azospirillum } \\
\text { (soil application before } \\
\text { transplanting) }\end{array}$ & 115.33 & 85.42 & 2.85 & 0.93 & 29.00 \\
\hline $\begin{array}{l}\mathrm{T}_{3}-\mathrm{RDF} 50 \%+\text { Azospirillum } \\
\text { (Seedling treatment) }\end{array}$ & 113.33 & 91.83 & 2.93 & 1.17 & 27.33 \\
\hline $\begin{array}{l}\mathrm{T}_{4}-\mathrm{RDF} 50 \%+\text { Azospirillum } \\
\text { (soil application at transplanting } \\
\text { treatment) }\end{array}$ & 109.00 & 92.92 & 3.18 & 1.20 & 26.67 \\
\hline $\begin{array}{l}\mathrm{T}_{5}-\mathrm{RDF} 50 \%+\text { Azospirillum (at } \\
25 \text { days after transplanting) }\end{array}$ & 116.33 & 84.92 & 2.81 & 0.96 & 29.00 \\
\hline $\begin{array}{l}\mathrm{T}_{6}-\mathrm{RDF} 50 \%+\text { Azospirillum (at } \\
25 \text { and } 50 \text { days after } \\
\text { transplanting) }\end{array}$ & 114.67 & 87.49 & 2.77 & 1.02 & 26.33 \\
\hline $\begin{array}{l}\mathrm{T}_{7}-\mathrm{RDF} 50 \%+\text { kitchen waste } \\
\text { manure (soil application before } \\
\text { transplanting ) }\end{array}$ & 112.67 & 86.16 & 2.77 & 1.05 & 23.67 \\
\hline $\begin{array}{l}\mathrm{T}_{8}-\mathrm{RDF} 50 \%+\text { kitchen waste } \\
\text { manure (at the time of } \\
\text { transplanting ) }\end{array}$ & 115.00 & 86.69 & 2.94 & 1.05 & 29.33 \\
\hline $\begin{array}{l}\mathrm{T}_{9}-\mathrm{RDF} 50 \%+\text { kitchen waste } \\
\text { manure ( } 25 \text { days after } \\
\text { transplanting ) }\end{array}$ & 112.00 & 89.92 & 2.88 & $1 . .06$ & 27.67 \\
\hline $\begin{array}{l}\mathrm{T}_{10}-\mathrm{RDF} 50 \%+\text { kitchen waste } \\
\text { manure }(25 \text { and } 50 \text { days after } \\
\text { transplanting })\end{array}$ & 107.67 & 96.07 & 3.35 & 1.37 & 28.33 \\
\hline $\begin{array}{l}\mathrm{T}_{11}-100 \% \text { kitchen waste manure } \\
\text { (at the time of transplanting) }\end{array}$ & 112.33 & 88.46 & 2.79 & 0.88 & 25.67 \\
\hline SEm ( \pm$)$ & 1.038 & 0.738 & 0.036 & 0.020 & 1.572 \\
\hline CD $(P=0.05)$ & 3.065 & 2.179 & 0.107 & 0.060 & N/A \\
\hline
\end{tabular}

Similarly, a significant increase on average fruit weight was also observed of physicchemical qualities of fruits. The application of $\mathrm{RDF} 50 \%$ and kitchen waste manure at 25 and 50 days after transplanting produced fruits with the highest average fruit weight of $3.35 \mathrm{~g}$ followed by application of RDF 50\% and Azospirillum as soil application during transplanting $\left(\mathrm{T}_{4}\right)$ as well as seedling transplanting $\left(\mathrm{T}_{3}\right)$. 
Mishra and Singh (2005) also noticed that NPK and Azotobactor significantly increase in okra, number of fruits, fruit length, fruit width, fruit size, average fruit weight and finally the yield was noted maximum under the treatment (Sewage Sludge @ $2.5 \mathrm{t}+3 / 4$ NPK + Azotobactor).

Maximum fruit thickness of pericarp(1.37 $\mathrm{mm}$ ) was recorded under treatment $\mathrm{T}_{10}$ followed by $\mathrm{T}_{4}$. The significant fruit thickness of pericarp increase was observed in all the treated plants a compared to control plants. According to the study by Gosavi et al., (2010) fruit quality parameter of tomato such as pericarp thickness found to be better in the treatment with organic fertilizers in combination bio-fertilizer.

The days from flowering to harvesting of green chilli fruits under $\mathrm{T}$ 7(RDF $50 \%+$ kitchen waste manure) showed the early from flowering to harvesting (23.67 days) followed by 25.67 days from flowering to harvesting and maximum days from flowering to harvesting of green chilli fruits 29.33 days under $\mathrm{T}_{8}(\mathrm{RDF} 50 \%$ + kitchen waste manure at the time of transplanting).

\section{Acknowledgments}

I would like to express my very great appreciation to Dr. Virendra Singh for his valuable and constructive suggestions during the planning and development of this research work.

\section{References}

Deshpande, R. P., Tamgadge, S., Deshmukh, A. and Deshmukh, S. 2010. Effect of organic and inorganic manures on growth and yield of chilli. International Journal of Forestry and Crop Improvement. 1(2): $146-48$.
Gosavi, P. U., Kamble, A. B. and Pandure, B. S. 2010. Effect of organic manures and biofertilizers on quality of tomato fruits. The Asian Journal of Horticulture 5(2):376-378.

Greenleaf, W.H., 1986.Pepper Breeding. AVI Publishing Co INC USA: 584. 67-134.

Jeevansab, 2000. Effect of nutrient sources on growth, yield and quality of capsicum (cv. California wonder) grown under different environments. M.Sc. (Agri.)Thesis, University of Agricultural Sciences, Dharwad.

Mishra, R. K. and Singh, G., 2005. Effect of sources of nutrients on performance of okra (Abelmschus esculentus L. Moench.) Sri Lankan Journal of Agriculture Sciences.42: $52-57$.

Natarajan, S, 1990. Standardization of nitrogen application for chilli (Capsicum annuum L.) growth under semi-dry condition. South Indian Horticulture. 47 (1-6): 252-254.

Pickersgill, B. 1997. Genetic resources and breeding of Capsicum spp. Euphytica. 96: 129-133.

Sajan, K. M., Gowda, K. K., Kumar, S. N. and Sreeramu, B. S. 2002. Effect of biofertilizers on growth and yield of chilli (Capsicum annuum L.) cv. Byadagi Dabba at different levels of nitrogen and phosphorus. Journal of Spices and Aromatic Crops. 11 (1): 58-61.

Siddesh, H. K. 2006. Studies on integrated nutrient management on seed yield and quality of chilli. Master of Science (Agriculture) Thesissubmitted to the University of Agricultural Sciences, Dharwad.

Sutagundi, R. H., 2000. Effect of mulches and manures on growth and yield of chilli(Capsicum annuum L.). M.Sc.(Agri.) Thesis, University of Agricultural Science, Dharwad, Karnataka, India.

Thamburaj,S. and Singh, Narendra. 2015. Text book of vegetables, tuber crops and spices. Indian Council of Agriculture Research, New Delhi. 


\section{How to cite this article:}

Vinit Kumar Meena, Sutanu Maji, Rakesh Kumar Meena and Batti Lal Meena. 2020. Effect of Bio-Fertilizer and Kitchen Waste Manure on Growth of Chilli cv. Pusa Jwala. Int.J.Curr.Microbiol.App.Sci. 9(06): 420-426. doi: https://doi.org/10.20546/ijcmas.2020.906.055 